\title{
Triacontanol Improves Production of Anticancer Alkaloids in Catharanthus roseus L.
}

\author{
M. Naeem ${ }^{1 *}$, Abid Ali Ansari', Tariq Aftab' ', M. Masidur Alam ${ }^{3}$, M. Masroor, A. Khan' and Moin Uddin ${ }^{4}$
}

'Department of Botany, Plant Physiology Section, Aligarh Muslim University, Aligarh, Uttar Pradesh, India; naeemgaur@gmail.com, tarik.alig@gmail.com, masruur@gmail.com ${ }^{2}$ Faculty of Science, Department of Biology, University of Tabuk, Tabuk - 71491, Saudi

Arabia; aansari@ut.edu.sa

3Department of Botany, Malda College, Malda, West Bengal, India; alam281@gmail.com

${ }^{4}$ Botany Section, Women's College, Aligarh Muslim University, Aligarh, Uttar Pradesh, India;

moinuddin202@rediffmail.com

\begin{abstract}
Catharanthus roseus (L.) G. Don is a medicinal plant that bears indole alkaloids used in cancer chemotherapy. The anticancer alkaloids, viz. vinblastine and vincristine, are mainly present in leaves of $C$. roseus. As there is high demand and low yield of these alkaloids in C. roseus, alternative ways to improve alkaloid production are needed. Hence, it was hypothesized that Triacontanol (TRIA), a potent plant growth promoting substance for various medicinal and agricultural crops, would improve alkaloid production in C. roseus. A pot culture experiment was carried out and the effects of TRIA on production of total alkaloids including anticancer alkaloids were evaluated at 120 and 150 days after planting. Four concentrations of TRIA $\left[10^{-0}\right.$ (Control) $10^{-7}, 10^{-6}$ and $10^{-5} \mathrm{M}$ ] were tested through leaf spraying. TRIA at $10^{-6} \mathrm{M}$ significantly increased yield attributes. As compared to the control $\left(10^{-0} \mathrm{M}\right)$, leaf-applied TRIA at $10^{-6} \mathrm{M}$ improved the production (yield) of anticancerous alkaloids vinblastine $(+71.6 \%)$ and vincristine $(+73.1 \%)$ and caused the highest content and yield of vindoline.
\end{abstract}

Keywords: Catharanthus roseus, Triacontanol (TRIA), Vinblastine, Vincristine, Vindoline Alkaloids

\section{Introduction}

Catharanthus roseus (L.) G. Don (commonly known in India as 'Sadabahar' or 'Periwinkle', family Apocynaceae) is a medicinal plant that produces chemotherapeutically important alkaloids, viz. vinblastine and vincristine. These alkaloids are mainly present in leaves of C. roseus and are able to inhibit the growth of cancer cells, hindering the formation of mitotic apparatus during cell division ${ }^{1}$. Further, vinblastine has helped increase the chance of surviving childhood leukaemia, while vincristine is used to treat Hodgkins' disease ${ }^{1}$. However, the content of these useful indole alkaloids is very low viz. $1 \mathrm{~g} \mathrm{t}^{-1}$ and $20 \mathrm{mg}$ $\mathrm{t}^{-1}$, respectively in C. roseus leaves. Efforts have been made to produce these alkaloids at large scale by cultures of plant cell suspensions and diverse tissues, such as hairy roots $^{2}$. However, it was found that C. roseus cell cultures lacked the part of biosynthetic pathway of vindoline and, hence, cells failed to synthesize these valuable and complex compounds for commercial use ${ }^{3}$. Tryptophan de-Carboxylase (TDC) is the key enzyme, involved in the early stages of indole alkaloid biosynthesis ${ }^{4}$, catalyzing the formation of tryptamine from tryptophan and, therefore, playing an important role in terpenoid indole alkaloids biosynthesis.

Triacontanol (TRIA), a long chain primary alcohol $\left(\mathrm{C}_{30} \mathrm{H}_{61} \mathrm{OH}\right)$, has been recognized as an important plant growth regulator for a number of $\operatorname{crops}^{5,6,7}$. TRIA

${ }^{*}$ Author for correspondence 
has improved growth, yield, quality and physiological processes of several medicinal plants viz. Artemisia annua, Coriandrum sativum, Cymbopogon flexuosus, Lavandula dentate, Mentha arvensis, Papaver somniferum, etc. by various workers ${ }^{8-11}$.

Due to the paramount medicinal importance of $C$. roseus, we hypothesized that foliar application of TRIA would enhance foliage yield and the overall production of anticancer (vinblastine and vincristine) alkaloids in $C$. roseus plants.

\section{Materials and Methods}

\subsection{Plant Materials and Growth Conditions}

A pot culture experiment was conducted in naturally illuminated environmental conditions of the net house at the Botany Department, Aligarh Muslim University, Aligarh, India. Healthy C. roseus seedlings of equal size were obtained from Woodbine Nursery, Civil Lines, Aligarh, India. The seedlings were then transplanted to earthen pots. Prior to transplantation, each pot (25 $\mathrm{cm}$ diameter $\times 25 \mathrm{~cm}$ height) was filled with $5 \mathrm{~kg}$ of homogenous mixture of soil and farmyard manure (4:1). Soil and chemical characteristics were: texture sandy loam, pH (1:2) 7.2, E.C. (1:2) $0.46 d S \mathrm{~m}^{-1}$, available N, $\mathrm{P}$ and $\mathrm{K}$ 95.0, 9.2 and $144.5 \mathrm{mg} \mathrm{kg}^{-1}$ of soil, respectively. The experiment was factorial design and arranged in randomized blocks. Each treatment was replicated five times and each replicate had three plants. Thus, each treatment consisted of 15 pots, and each pot contained a single healthy plant. The pots were sufficiently watered as required and plants did not face water deficit.

\subsection{Treatments}

Foliar spray of different concentrations of TRIA was done at 15 days interval when plants were at stage of 2-3 true leaves. In total, five sprays of TRIA were done using a hand sprayer. The control plants were sprayed with double distilled water only. The applied treatments were: Control (deionised water, $10^{-0}$ ), $10^{-7}, 10^{-6}$ and $10^{-5}$ M TRIA. Different aqueous concentrations of TRIA were finally prepared using double distilled water for the spray treatments on plants. Plants were sampled for yield and quality parameters carried out at 120 and 150 DAP. At sampling (120 and 150 DAP), five plants of each treatment were harvested and their roots were washed carefully with tap water to remove all adhering foreign particles. Water adhering to the roots was removed with blotting paper. Then, the plant fresh and dry weights were measured using an electronic balance.

\subsection{Yield Attributes}

Leaf-yield was recorded by weighing all plant leaves with an electronic balance, whereas herbage-yield was measured weighing the total plant biomass with exception of roots.

\subsection{Total Alkaloid Content in Leaves and Roots}

Total alkaloid content was estimated in leaves and roots. The detailed methodology for the estimation of total alkaloids content has already been described in our previous studies ${ }^{12,13}$. The leaves and roots were dried in a hot air oven at $80^{\circ} \mathrm{C}$ for twenty-four hours. Five hundred $\mathrm{mg}$ of the powdered sample was taken in a100 $\mathrm{mL}$ round bottom reflux flask. To it, a known volume of ethyl alcohol was added. Then, the mixture was refluxed for 6 hours. Thereafter, it was filtered, followed by adding $50 \mathrm{~mL}$ of dilute $\mathrm{HCl}$, and then the filtrate was transferred to a separating funnel, to which $50 \mathrm{~mL}$ of diethyl ether was added. To the final decant, anhydrous sodium carbonate was added. Then, the mixture was decanted in a preweighed dry porcelain dish, followed by evaporating the content till dryness; lastly, the dried content was weighed. Total alkaloid content in leaves/roots was calculated as per the formula described in the previous studies $^{12}$.

\subsection{Content of Vincristine, Vinblastine and Vindoline Alkaloids}

Preparation of sample extraction and the chromatographic conditions were based on the method ${ }^{14}$. Freshly harvested leaves were oven dried at $80^{\circ} \mathrm{C}$ for $24 \mathrm{~h}$ and then grinded to fine powder. A volume $(30 \mathrm{~mL})$ of $90 \%$ ethanol was added to $5 \mathrm{~g}$ of leaf powder; it was left over night and then filtered. The residue was again extracted with $90 \%$ ethanol $(3 \times 30 \mathrm{~mL})$ at room temperature $\left(27^{\circ} \mathrm{C}\right)$, and the pooled alcoholic extract was filtered and concentrated in vacuo at $40^{\circ} \mathrm{C}$. The dried residue was re-dissolved in ethanol $(10$ $\mathrm{mL})$, diluted with water $(10 \mathrm{~mL})$ and then acidified with $3 \%$ hydrochloric acid $(10 \mathrm{~mL})$. This was then extracted with hexane $(3 \times 30 \mathrm{~mL})$. The hexane extract was discarded, and the aqueous portion was cooled at $10^{\circ} \mathrm{C}$. Afterwards, it was basified with ammonium hydroxide 
to $\mathrm{pH} 8.5$ and then was extracted with chloroform $(3 \times$ $30 \mathrm{~mL}$ ). The combined chloroform extract was washed with water, evaporated to dryness and re-dissolved in $1 \mathrm{~mL}$ of chloroform. After that, it was passed through a silica Sep-Pak cartridge (Waters), pre-saturated with chloroform. Then, it washed successively with $5 \mathrm{~mL}$ each of chloroform and chloroform-methanol mixture (9:1, $\mathrm{v} / \mathrm{v})$ and dried over anhydrous sodium sulphate before being evaporated to dryness. The residue obtained was dried to constant weight in order to determine the total alkaloid content. An aliquot (10 mg) of the crude alkaloid was dissolved in $1 \mathrm{~mL}$ of methanol, and $10 \mu \mathrm{L}$ of it was subjected to HPLC analysis.

Chromatographic analysis was carried out using HPLC (model LC-10A, Shimadzu, Tokyo, Japan). Solvents were filtered by using a Millipore system and analysis was performed on a Waters $\mu$ Bondapak $\mathrm{C}_{18}$ reversedphase column, $10 \mathrm{~mm}(30 \mathrm{~cm} \times 3.9 \mathrm{~mm}$ I.D. $)$. A constant flow rate of $0.6 \mathrm{~mL} \mathrm{~min}^{-1}$ was used during analysis. The composition of mobile phase was optimized by using acetonitrile, $0.1 \mathrm{M}$ phosphate buffer and glacial acetic acid (38:62:0.3); $\mathrm{pH} 4.14$, column temperature of $26^{\circ} \mathrm{C}$, detector (UV-Vis detector) at $254 \mathrm{~nm}$. For standard, stock solutions of vinblastine, vincristine and vindoline were prepared dissolving $1 \mathrm{mg}$ of each in $1 \mathrm{~mL}$ of methanol. The solutions were analyzed and the retention time (Rt) for vinblastine (Rt-5 min), vincristine (Rt-4 min) and vindoline (Rt-10 $\mathrm{min}$ ) were checked.

\subsection{Statistical Analysis}

The data were analyzed statistically using SPSS-17 statistical software (SPSS Inc., Chicago, IL, USA) according to simple randomized design. Means were compared using Duncan's Multiple Range Test (DMRT) at $\mathrm{p}<0.05$.

\section{Results}

Compared to the other foliar concentrations, TRIA applied at $10^{-6} \mathrm{M}$ concentrations proved to be the best. TRIA, applied at $10^{-6} \mathrm{M}$, improved yield and quality attributes of the crop significantly at both the growth stages. However, TRIA applied at $10^{-5} \mathrm{M}$ did not further improve all the attributes but it significantly enhanced the above studied attributes in comparison to control. Except on the content of vinblastine and vincristine, the effect of TRIA treatments, growth stages and of TRIA $\times$ Stage

Table 1. Effect of four foliar concentrations of TRIA on leaf and herbage yields, content and yield of leaf and root alkaloids per plant of C. roseus L. at 120 and 150 DAP. Means within a column followed by the same letter(s) are not significantly different $(\mathrm{p} \leq 0.05)$

\begin{tabular}{|c|c|c|c|c|c|c|c|}
\hline DAP & $\begin{array}{l}\text { Treatments } \\
(\mathrm{M})\end{array}$ & $\begin{array}{l}\text { Leaf yield } \\
\text { per plant (g) }\end{array}$ & $\begin{array}{l}\text { Herbage yield } \\
\text { per plant }(\mathrm{g})\end{array}$ & $\begin{array}{l}\text { Leaf alkaloids } \\
\text { content }(\%)\end{array}$ & $\begin{array}{l}\text { Leaf alkaloids } \\
\text { yield }(\mu \mathrm{g})\end{array}$ & $\begin{array}{l}\text { Root alkaloids } \\
\text { content }(\%)\end{array}$ & $\begin{array}{l}\text { Root alkaloids } \\
\text { yield }(\mu \mathrm{g})\end{array}$ \\
\hline \multirow[t]{4}{*}{120} & TRIA $10^{-0}(\mathrm{M})$ & 53.75 & 62.35 & 0.740 & 85.0 & 1.56 & 46.0 \\
\hline & TRIA $10^{-7}(\mathrm{M})$ & 59.10 & 68.63 & 0.770 & 90.0 & 1.62 & 57.6 \\
\hline & TRIA $10^{-6}(\mathrm{M})$ & 67.72 & 80.74 & 0.821 & 106.1 & 1.72 & 72.2 \\
\hline & TRIA $10^{-5}(\mathrm{M})$ & 64.70 & 75.40 & 0.810 & 104.1 & 1.69 & 70.0 \\
\hline \multirow[t]{4}{*}{150} & TRIA $10^{-0}(\mathrm{M})$ & 56.36 & 66.74 & 0.770 & 88.0 & 1.60 & 67.0 \\
\hline & TRIA $10^{-7}(\mathrm{M})$ & 62.50 & 76.96 & 0.820 & 96.0 & 1.68 & 79.4 \\
\hline & TRIA $10^{-6}(\mathrm{M})$ & 72.70 & 89.76 & 0.870 & 112.7 & 1.80 & 108.8 \\
\hline & TRIA $10^{-5}(\mathrm{M})$ & 68.45 & 84.64 & 0.850 & 110.0 & 1.77 & 106.5 \\
\hline \multirow{4}{*}{$\begin{array}{l}\text { Means of } \\
\text { Treatments }\end{array}$} & TRIA $10^{-0}(\mathrm{M})$ & $55.05^{\mathrm{d}}$ & $64.54^{\mathrm{d}}$ & $0.755^{c}$ & $86.5^{c}$ & $1.58^{c}$ & $56.5^{\mathrm{d}}$ \\
\hline & TRIA $10^{-7}(\mathrm{M})$ & $60.80^{c}$ & $72.79^{c}$ & $0.795^{\mathrm{b}}$ & $93.0^{\mathrm{b}}$ & $1.65^{\mathrm{b}}$ & $68.5^{c}$ \\
\hline & TRIA $10^{-6}(\mathrm{M})$ & $70.21^{\mathrm{a}}$ & $85.25^{\mathrm{a}}$ & $0.845^{\mathrm{a}}$ & $109.4^{\mathrm{a}}$ & $1.76^{\mathrm{a}}$ & $90.5^{\mathrm{a}}$ \\
\hline & TRIA $10^{-5}(\mathrm{M})$ & $66.57^{\mathrm{b}}$ & $80.02^{\mathrm{b}}$ & $0.830^{\mathrm{ab}}$ & $107.0^{\mathrm{ab}}$ & $1.73^{\mathrm{ab}}$ & $88.2^{\mathrm{b}}$ \\
\hline \multirow{2}{*}{$\begin{array}{l}\text { Means of } \\
\text { Stages }\end{array}$} & $120 \mathrm{DAP}$ & $61.32^{\mathrm{b}}$ & $71.78^{\mathrm{b}}$ & $0.785^{\mathrm{b}}$ & $96.3^{\mathrm{b}}$ & $1.65^{\mathrm{b}}$ & $61.4^{\mathrm{b}}$ \\
\hline & 150 DAP & $65.00^{\mathrm{a}}$ & $79.52^{\mathrm{a}}$ & $0.827^{a}$ & $101.7^{\mathrm{a}}$ & $1.71^{\mathrm{a}}$ & $90.4^{\mathrm{a}}$ \\
\hline \multirow[t]{3}{*}{ LSD at $5 \%$} & $\mathrm{~T}$ & 2.40 & 3.24 & 0.02 & 2.8 & 0.03 & 2.1 \\
\hline & $\mathrm{S}$ & 2.48 & 3.12 & 0.02 & 2.9 & 0.03 & 1.6 \\
\hline & $\mathrm{T} \times \mathrm{S}$ & 4.88 & 6.36 & 0.04 & 5.7 & 0.06 & 3.7 \\
\hline
\end{tabular}

T: Treatments; S: Stages 
Table 2. Effect of four foliar concentrations of TRIA on content and yield of vinblastine, vincristine and vindoline of $C$. roseus $\mathrm{L}$. studied at 120 and $150 \mathrm{DAP}$. Means within a column followed by the same letter(s) are not significantly different $(\mathrm{p} \leq 0.05)$

\begin{tabular}{|c|c|c|c|c|c|c|c|}
\hline DAP & $\begin{array}{l}\text { Treatments } \\
\text { (M) }\end{array}$ & $\begin{array}{l}\text { Vinblastine } \\
\text { content (\%) }\end{array}$ & $\begin{array}{l}\text { Vinblastine } \\
\text { yield }(\mu \mathrm{g})\end{array}$ & $\begin{array}{l}\text { Vincristine } \\
\text { content (\%) }\end{array}$ & $\begin{array}{l}\text { Vincristine } \\
\text { yield }(\mu \mathrm{g})\end{array}$ & $\begin{array}{l}\text { Vindoline } \\
\text { content (\%) }\end{array}$ & $\begin{array}{l}\text { Vindoline } \\
\text { yield }(\mu \mathrm{g})\end{array}$ \\
\hline \multirow[t]{4}{*}{120} & TRIA $10^{-0}(\mathrm{M})$ & 0.016 & 14.0 & 0.0032 & 3.70 & 0.049 & 38.0 \\
\hline & TRIA $10^{-7}(\mathrm{M})$ & 0.017 & 18.0 & 0.0032 & 5.33 & 0.054 & 60.0 \\
\hline & TRIA $10^{-6}(\mathrm{M})$ & 0.017 & 23.9 & 0.0032 & 6.20 & 0.060 & 71.0 \\
\hline & TRIA $10^{-5}(\mathrm{M})$ & 0.017 & 23.0 & 0.0032 & 6.00 & 0.056 & 69.0 \\
\hline \multirow[t]{4}{*}{150} & TRIA $10^{-0}(\mathrm{M})$ & 0.017 & 17.0 & 0.0037 & 4.10 & 0.067 & 72.0 \\
\hline & TRIA $10^{-7}(\mathrm{M})$ & 0.018 & 24.0 & 0.0036 & 5.90 & 0.074 & 105.0 \\
\hline & TRIA $10^{-6}(\mathrm{M})$ & 0.018 & 29.3 & 0.0037 & 7.30 & 0.080 & 137.0 \\
\hline & TRIA $10^{-5}(\mathrm{M})$ & 0.017 & 28.6 & 0.0036 & 7.10 & 0.077 & 135.0 \\
\hline \multirow{4}{*}{$\begin{array}{l}\text { Means of } \\
\text { Treatments }\end{array}$} & TRIA $10^{-0}(\mathrm{M})$ & 0.016 & $15.5^{\mathrm{d}}$ & 0.0034 & $3.90^{c}$ & $0.058^{c}$ & $55.0^{c}$ \\
\hline & TRIA $10^{-7}(\mathrm{M})$ & 0.017 & $21.0^{c}$ & 0.0034 & $5.61^{\mathrm{b}}$ & $0.064^{\mathrm{b}}$ & $82.5^{\mathrm{b}}$ \\
\hline & TRIA $10^{-6}(\mathrm{M})$ & 0.017 & $26.6^{\mathrm{a}}$ & 0.0035 & $6.75^{\mathrm{a}}$ & $0.070^{\mathrm{a}}$ & $104.0^{\mathrm{a}}$ \\
\hline & TRIA $10^{-5}(\mathrm{M})$ & 0.017 & $25.8^{\mathrm{b}}$ & 0.0034 & $6.55^{\mathrm{ab}}$ & $0.066^{\mathrm{ab}}$ & $102.0^{\mathrm{ab}}$ \\
\hline \multirow{2}{*}{$\begin{array}{l}\text { Means of } \\
\text { Stages }\end{array}$} & 120 DAP & 0.016 & $19.7^{\mathrm{b}}$ & 0.0032 & $5.31^{\mathrm{b}}$ & $0.055^{\mathrm{b}}$ & $59.5^{\mathrm{b}}$ \\
\hline & $150 \mathrm{DAP}$ & 0.017 & $24.7^{\mathrm{a}}$ & 0.0036 & $6.10^{\mathrm{a}}$ & $0.074^{\mathrm{a}}$ & $112.2^{\mathrm{a}}$ \\
\hline \multirow[t]{3}{*}{ LSD at $5 \%$} & $\mathrm{~T}$ & NS & 0.30 & NS & 0.28 & 0.002 & 2.50 \\
\hline & $S$ & NS & 0.40 & NS & 0.51 & 0.002 & 2.60 \\
\hline & $\mathrm{T} \times \mathrm{S}$ & NS & 0.70 & NS & 0.80 & 0.004 & 5.10 \\
\hline
\end{tabular}

T: Treatments; S: Stages

interaction $(\mathrm{T} \times \mathrm{S})$ was significant on all the parameters studied, (Tables 1-2).

\subsection{Yield and Quality Attributes}

TRIA, applied at $10^{-6} \mathrm{M}$ concentration, excelled the control in leaf yield by $27.5 \%$ and in herbage yield by $32.1 \%$ (Table 1). Application of TRIA increased the content and yield of alkaloids when compared to the control. The spray of TRIA at the concentration of $10^{-6}$ $M$ resulted in the maximum increase in the content and yield of leaf alkaloids. It exceeded the control by $11.9 \%$ in leaf alkaloids content and by $26.4 \%$ in leaf alkaloids yield (Table 1). Comparing the control, the foliar spray of $10^{-6} \mathrm{M}$ TRIA also increased the content and yield of root alkaloids. It increased the root alkaloids content by $11.4 \%$ and the root alkaloids yield by $60.2 \%$ (Table 1 ). Plants of 150 DAP surpassed 120 DAP by 6.0 and $10.8 \%$ regarding leaf and herbage yield, respectively, (Table 1). Further, 150 DAP plants produced 5.35, 5.61, 3.64 and $47.2 \%$ higher values for content and yield of leaf and root alkaloids, respectively over 120 DAP plants, (Table 1). Noticeably, the effect of TRIA treatments, stages differences, and TRIA-stages interaction was found significant for leaf yield, herbage yield, content and yield of leaf and root alkaloids (Table 1$)$. Interactions $\mathrm{T} \times \mathrm{S}\left(10^{-6} \mathrm{M}\right.$ TRIA- 150 DAP), exhibited the highest content (17.6 and 15.4\%) and yield (32.6 and 136.5\%) of leaf and root alkaloids, respectively over $10^{-0} \mathrm{M}$ TRIA-120 DAP, the poorest interaction (Table 1).

In the present study, there was observed no progressive increase in anticancer constituents (content of vinblastine and vincristine) as compared to the control, when TRIA was applied to the $C$. roseus crop (Table 2). The TRIA spray at $10^{-6} \mathrm{M}$ considerably increased the yields of vinblastine and vincristine. It increased the vinblastine yield by $71.6 \%$ and vincristine yield by $73.1 \%$, as compared to the control (Table 2). Besides, the application of TRIA at $10^{-6} \mathrm{M}$ resulted in the maximum content and yield of vindoline. It increased the vindoline content by $20.7 \%$ and vindoline yield by $89.1 \%$ as compared to the control (Table 2).

Plants of 150 DAP produced higher yields of vinblastine, vincristine and vindoline over $120 \mathrm{DAP}$, the 
former surpassing the latter by $25.4,14.9 \%$ and $19.0 \%$, respectively. TRIA effect, stages differences and TRIAStage interaction were found non-significant for content of vincristine and vinblastine (Table 2). However, interaction of $10^{-6} \mathrm{M}$ TRIA-150 DAP for vinblastine and vincristine content was found significant and showed higher values for the above parameters by 109.3 and $97.3 \%$, respectively over $10^{-0} \mathrm{M}$ TRIA-120 DAP, the poorest interaction (Table 2). Treatment effect, stages differences and their interaction was also found significant for content and yield of vindoline alkaloid (Table 2). Interaction of $10^{-6} \mathrm{M}$ TRIA-150 DAP, gave higher values for content (36.7\%) and yield (89.5\%) of vindoline, exceeding the interaction $10^{-0} \mathrm{M}$ TRIA-120 DAP, which showed lowest value, (Table 2).

\section{Discussion}

The effect of TRIA has previously been well established in plant productivity, ${ }^{5,6}$. TRIA significantly improved the yield attributes over their respective plants (Table 1). A significant increase in the above-mentioned yield parameters of the TRIA treated plants might possibly culminate in maximization of the leaf-yield and herbage yield of the plant in the present study. The positive role of TRIA in increasing growth, yield and quality as well as physiological processes in various medicinal plants including Artemisia annua L. ${ }^{9}$, Coriandrum sativum L. ${ }^{15,16}$, Cymbopogon flexuosus Steud, Watts. ${ }^{10}$, Mentha arvensis L. ${ }^{11,17}$, Papaver somniferum $\mathrm{L} .{ }^{18}$ and Withania somnifera $\mathrm{L} .{ }^{19}$ has earlier been reported. Study suggested ${ }^{5}$ that TRIA, like other plant hormones might activate enzymes or alter a membrane, which could trigger a cascading effect resulting in increased metabolism and the enhanced accumulation of various critical intermediate compounds. The increase in the quality parameters like EO content in lavender, spearmint, Japanese mint, and coriander as a result of application of ethrel, gibberellic acid and TRIA has been reported by various researchers ${ }^{11,17,20}$. Presumably, as a result of application of TRIA, in turn, enhanced the rate of photosynthesis and translocation of photosynthates and other metabolites to the sinks ${ }^{17,21}$ leading to the improved yield and its attributes in this study (Tables 1,2). Regarding TRIA, our results are in agreement with those of other researchers who reported enhancement in the seed-yield and yield attributes due to TRIA ${ }^{8,21,22}$.

This study reports significant enhancement in the alkaloid production as result of TRIA application (Table 1).
A positive role of growth hormones in regulation of indole alkaloids of periwinkle has been reported ${ }^{23,24}$. PGRs have, in fact, been reported to affect the tissue specific secondary metabolism and manipulate the alkaloid accumulation at particular sites ${ }^{25}$. Other PGRs also exerted a significant effect on alkaloid production and similar results were reported ${ }^{25}$. Distribution and accumulation of alkaloids in plant parts may vary in roots, stems, and leaves of C. roseus ${ }^{26}$. TRIA enhanced the yield of vincristine alkaloid as well (Table 2). Besides, Salicylic acid (SA) has been reported to increase the production of other alkaloids such as serpentine and tabersonine ${ }^{27}$. Similarly, SA could induce the accumulation of vindoline alkaloid in Catharanthus seedlings ${ }^{27}$. MS medium supplied with 2,4-D, KIN, and IAA enhanced the production of vincristine and vinblastine alkaloids during in vitro culture ${ }^{28}$. Reported ${ }^{24}$ an SA-mediated accumulation of vincristine and vinblastine alkaloids under salinity stress in C. roseus. Noted ${ }^{9}$ a significant enhancement in the artemisinin content of Artemisia annua. Found ${ }^{8}$ a significant positive effect of cumulative application of TRIA and $\mathrm{GA}_{3}$ on the yield of opium (Papaver somniferum L.) and its morphine content. Study examined ${ }^{18}$ the effect of TRIA on alkaloid-biosynthesis as well as on the relationship between alkaloid production and physiological parameters in opium poppy.

Plants of C. roseus at 150 DAP exhibited a better performance than that at 120 DAP in respect to growth attributes, physiological and biochemical parameters, and yield and quality attributes. Variation in two growth stages occurred due to more number of leaves and biomass production as plants continued to grow irrespective to treatments. In the agro-climatic conditions of India, the above variations regarding several physiological and morphological traits in C. roseus have also been recorded in our previous study ${ }^{12,29}$. Interaction of $10^{-6} \mathrm{M}$ TRIA-150 DAP, exhibited higher values for almost all parameters studied, exceeding the interaction $10^{-0} \mathrm{M}$ TRIA-120 DAP, which is proved poorest interaction (Table 2). Interactions between them, that impact on crop performance and yield.

\section{Conclusions}

Triacontanol at $10^{-6} \mathrm{M}$ improved significantly the production (in terms of yield) of vincristine, vinblastine and vindoline of $C$. roseus. Thus, application of TRIA as foliar spray could be used to enhance the anticancer alkaloids production in $C$. roseus. 


\section{Acknowledgements}

Financial support to the awardee of Young Scientist (Project no. CST/1235) to Dr. M. Naeem by the Council of Science and Technology, UP, Lucknow, India, is gratefully acknowledged.

\section{References}

1. Gueritte F, Fahy J. The vinca alkaloids. In: G.M., Cragg, D.G.I., Kingston, D.J., Newman, (Eds.), Anticancer Agents from Natural Products. Runner-Routledge Psychology Press, Taylor and Francis Group, Boca Raton, FL; 2005. 123-36. https://doi.org/10.1201/9781420039658.ch7.

2. Oksman-Caldentey KM, Inze D. Plant cell factories in the post-genomic era: New ways to produce designer secondary metabolites, Trends in Plant Science. 2004; 9:433-440. https://doi.org/10.1016/j.tplants.2004.07.006. PMid: 15337493.

3. Zhao J, Verpoorte R. Manipulating indole alkaloid production by Catharanthus roseus cell cultures in bioreactors: From biochemical processing to metabolic engineering, Phytochemistry Review. 2007; 6:435-57. https://doi. org/10.1007/s11101-006-9050-0.

4. Facchini PJ, Huber-Allanach KL, Tari LW. Plant aromatic L-amino acid decarboxylases: Evolution, biochemistry, regulation, and metabolic engineering applications, Phytochemistry. 2000; 54:121-38. https://doi.org/10.1016/ S0031-9422(00)00050-9.

5. Ries SK, Houtz RL. Triacontanol levels in ascending sugar maple sap, Hort. Science. 1983; 18:101-02.

6. Ries S. Triacontanol and its second messenger $9-\beta-\mathrm{L}(+)-$ adenosine as plant growth substances, Plant Physiology. 1991; 95:986-89. https://doi.org/10.1104/pp.95.4.986. PMid: 16668132.

7. Naeem M, Khan MMA, Moinuddin. Triacontanol: A potent plant growth regulator in agriculture, Journal of Plant Interactions. 2012; 7:129-42. https://doi.org/10.1080 /17429145.2011.619281.

8. Khan R, Khan MMA, Singh M, Nasir S, Naeem M, Siddiqui $\mathrm{MH}$, Mohammad F. Gibberellic acid and triacontanol can ameliorate the optimum yield and morphine production in opium poppy (Papaver somniferum L.), Acta Agriculturae Scandinavica, Section B-Soil and Plant Science. 2007; 57:307-12. https://doi.org/10.1080/09064710600982811.

9. Aftab T, Khan MMA, Idrees M, Naeem M, Singh M, Ram M. Stimulation of crop productivity, photosynthesis and artemisinin production in Artemisia annua L. by triacontanol and gibberellic acid application, Journal of Plant Interactions. 2010; 5:273-81. https://doi. org/10.1080/17429141003647137.
10. Misra A, Srivastava NK. Effects of the triacontanol formulations "Miraculan" on photosynthesis, growth, nutrient uptake, and essential oil yield of lemongrass (Cymbopogon flexuosus) Steud, Watts, Plant Growth Regulation. 1991; 10:57-63. https://doi.org/10.1007/BF00035131.

11. Srivastava NK, Sharma S. Effect of triacontanol on photosynthetic characters and essential oil accumulation in Japanese mint (Mentha arvensis L.), Photosynthetica. 1991; 25:55-60.

12. Naeem M, Aftab T, Ansari AA, Idrees M, Ali A, Khan MMA, Uddin M, Varshney L. Radiolytically degraded sodium alginate enhances plant growth, physiological activities and alkaloids production in Catharanthus roseus L, Journal of Radiation Research and Applied Sciences. 2015a; 8:606-16. https://doi.org/10.1016/j.jrras.2015.07.005.

13. Naeem M, Idrees M, Aftab T, M. Masidur Alam MM, Khan MMA, Uddin M, Varshney L. Radiation processed carrageenan improves plant growth, physiological activities and alkaloids production in Catharanthus roseus L, Advances in Botany Article ID 150474. 2015; 2015b:1-11. https://doi. org/10.1155/2015/150474.

14. Uniyal GC, Bala S, Mathur AK, Kulkarni RN. Symmetry C18 column: a better choice for the analysis of indole alkaloids of Catharanthus roseus, Phytochemical Analysis. 2001; 12:206-10. https://doi.org/10.1002/pca.575. PMid: 11705028.

15. Idrees M, Khan MMA, Aftab T, Naeem M. Synergistic effects of gibberellic acid and triacontanol on growth, physiology, enzyme activities and essential oil content of Coriandrum sativum L, The Asian and Australasian Journal of Plant Science and Biotechnology. 2010; 4:24-29.

16. Karam EA, Keramat B, Asrar Z, Mozafari H. Triacontanolinduced changes in growth, oxidative defense system in coriander (Coriandrum sativum) under arsenic toxicity, Physiol. Mol. Biol. Plants. 2016; 22:341-49. https://doi. org/10.1007/s40502-016-0213-8.

17. Naeem M, Khan MMA, Moinuddin, Idrees M, Aftab T. Triacontanol-mediated regulation of growth and other physiological attributes, active constituents and yield of Mentha arvensis L, Plant Growth Regulation. 2011; 65:195-206. https://doi.org/10.1007/s10725-011-9588-8.

18. Srivastava NK, Sharma S. Effect of triacontanol on photosynthesis, alkaloid content and growth in opium poppy (Papaver somniferum L), Plant Growth Regulation. 1990; 9:65-71. https://doi.org/10.1007/BF00025280.

19. Nasir S. Influence of Triacontanol and Macronutrient Elements on the Growth, Yield and Alkaloid Content of Withania Somnifera Dunal. L. and Datura Innoxia Mill. PhD Thesis, AMU, Aligarh, India; 2009.

20. Singh $P$, Srivastava NK, Mishra A, Sharma S. Influence of ethrel and gibberellic acid on carbon metabolism, 
growth, essential oil accumulation in spearmint (Mentha spicata), Phtosynthetica. 1999; 36:509-17. https://doi. org/10.1023/A:1007083802765.

21. Naeem M, Khan MMA, Moinuddin, Siddiqui MH. Triacontanol stimulates nitrogen-fixation, enzyme activities, photosynthesis, crop productivity and quality of hyacinth bean (Lablab purpureus L.), Scientia Horticulturae. 2009; 121:389-96. https://doi.org/10.1016/j. scienta.2009.02.030.

22. Naeem M, Idrees $M$, Aftab T, Khan MMA, Moinuddin. Changes in photosynthesis, enzyme activities and production of anthraquinone and sennoside content of coffee senna (Senna occidentalis L.) by triacontanol, International Journal of Plant Developmental Biology. 2010; 4:53-59.

23. Moreno PRH, Van der Heijden R, Veerporte R. Cell and tissue cultures of Catharanthus roseus, Plant Cell and Tissue Organ Culture. 1995; 42:1-25. https://doi.org/10.1007/ BF00037677.

24. Idrees M, Naeem M, Aftab T, Khan MMA, Moinuddin. Salicylic acid mitigates salinity stress by improving antioxidant defence system and enhances vincristine and vinblastine alkaloids production in periwinkle [Catharanthus roseus (L.) G. Don], Acta Physiologiae Plantarum. 2011; 33:987-99. https://doi.org/10.1007/s11738-010-0631-6.
25. Srivastava NK, Srivastava AK. Influence of gibberellic acid on 14CO2 metabolism, growth, and production of alkaloids in Catharanthus roseus, Photosynthetica. 2007; 45:156-60. https://doi.org/10.1007/s11099-007-0026-0.

26. Misra P, Kumar S. Emergence of periwinkle (Catharanthus roseus) as a model system for molecular Biology of alkaloid: Phytochemistry, pharmacology, plant biology and in vivo and in vitro cultivation, J. Med. Arom. Plant Sci. 2000; 22:306-37.

27. El-Sayed M, Verpoorte R. Growth, metabolic profiling and enzymes activities of Catharanthus roseus seedlings treated with plant growth regulators, Plant Growth Regulation. 2004; 44:53-58. https://doi.org/10.1007/s10725-004-2604-5.

28. Ataei-Azimi A, Hashemloian BD, Ebrahimzadeh H, Majd A. High in vitro production of ant-canceric indolealkaloids from periwinkle (Catharanthus roseus) tissue culture, African Journal of Biotechnology. 2008; 7:2834-39.

29. Alam M, Naeem M, Idrees $M$, Khan MMA, Moinuddin. Augmentation of photosynthesis, crop productivity, enzyme activities and alkaloids production in sadabahar (Catharanthus roseus L.) through application of diverse plant growth regulators, Journal of Crop. Science and Biotechnology. 2012; 15:117-29. https://doi.org/10.1007/ s12892-011-0005-7. 